\title{
Non-dirt house floor and the stimulant of environmental health decreased the risk Acute Respiratory Infection (ARI)
}

\author{
Putu Suriyasa $^{*}$, Balgis ${ }^{*}$, Ristu Saptono ${ }^{f}$, Mantrini Indri Hapsari ${ }^{*}$
}

\begin{abstract}
Abstrak
Beberapa faktor terkait dengan infeksi saluran napas atas (ISPA) antara lain lantai rumah. Tujuan penelitian adalah untuk mengetahui dampak program kesehatan keluarga dan gizi $(K K G)$ dan beberapa faktor risiko yang lain yang berkaitan dengan ISPA. Data berasal dari survey yang dilakukan di 5 provinsi di Indonesia, pada projek KKG pada tahun 2003. Subjek terdiri dari 1.500 keluarga yang dipilih dengan cara stratifikasi random. Interview dan observasi ke rumah subjek dilakukan oleh petugas yang terlatih khusus untuk penelitian ini. Lantai rumah yang berupa bukan tanah yang dibuat sebelum projek KKG menurunkan risiko ISPA sebesar $51 \%$ dibandingkan dengan rumah yang berlantai tanah [Rasio Odds $(O R)=0.49 ; 95 \%$ interval kepercayaan $(C I)=0,25$ 0,96]. Risiko ISPA berkurang 52\% di antara mereka yang menerima bantuan dibandingkan dengan yang tidak menerima stimulan kesehatan lingkungan projek KKG $(O R=0.48 ; 95 \% C I=0.33-0.70)$. Disimpulkan bahwa untuk menurunkan risiko ISPA, program stimulan kesehatan lingkungan dapat dilanjutkan. (Med J Indones 2006; 15:60-5)
\end{abstract}

\begin{abstract}
The risk factors related to acute respiratory infection (ARI), among others, is house floor. The aim of this research was to identify the influence of the Family Health and Nutrition program (FHN) and other risk factors related to ARI. Data was obtained from a survey conducted in 5 provinces in Indonesia, which received the project of Family Health and Nutrition (FHN) in 2003. The number of subjects was 1,500 families, selected by stratified random sampling method. The questionnaire completion and the observation were done on the spot in the subject's house by special trained interviewers. The use of non-dirt house floor built prior to the project of FHN decreased the risk of ARI cases of $51 \%$ than the use of dirt house floor [Odds Ratio $($ OR $)=0.49 ; 95 \%$ Confidence Interval (CI) $=0.25-0.96]$. The risk of ARI decreased of 52\% among those who received than those which never received the stimulant of environmental health Family Health and Nutrition program $(O R=0.48 ; 95 \% C I=0.33-0.70)$. To decrease the risks of ARI cases, the program of environmental health is necessarily continued. (Med J Indones 2006; 15:60-5)
\end{abstract}

Keywords: ARI, non-dirt house floor, and stimulant of environmental health.

Acute Respiratory Infection (ARI) is the main cause of illness and death all over the world. ARI cause more than four million childhood deaths each year in developing countries. ${ }^{1}$ The studies conducted over several countries show that a child will, in average, experience episodes of ARI attack, 7,2 episodes/year in Guatemalan. In Bangladesh 11.2 episodes per childyear, the highest (14.9) and lowest (8.8) rates per child-year. ${ }^{2,3,4}$

\footnotetext{
* The Study Program of Family Medicine, Postgraduate Program, Sebelas Maret University, Surakarta, Indonesia

$f$ The Study Program of Mathematics, Faculty of Teacher Training and Education, Sebelas Maret University, Surakarta, Indonesia
}

The community's social economy environment, behavior, and nutrition status, which include parents' education, settlement density, house type, house ventilation, illumination, behavior which produce increasing amount of pollution in rooms such as smoking, and malnutrition are some of the factors contributing to the risks of ARI. In addition, the mother's breast milk also takes a part in the increase of respiratory tract diseases. ${ }^{5,6}$

In order to improve the community's behavior, the Government of Indonesia represented by the Health Department of Republic of Indonesia has introduced the indicators of the Healthy Family Potential Index (HFPI) through the project of FHN: the availability of potable water infrastructures, the availability of family 
latrine, the building of non-dirt house floor, Family Planning program implementation (particularly for couples in productive ages), children growth monitoring (for family with under five year children), no-smoking members of family, and being the members of JPKM/Health Insurance/Health Fund). These indicators are very simple and can be used to predict both the family health status and the local community health status. $^{7}$

Based on the above explanation, the aim of the research is to find out how far the indicators of the HFPI and other environmental variables influence the risks of ARI cases.

\section{METHODS}

This cross sectional approach ${ }^{8}$ was one of studies conducted to evaluate the implementation of the project of FHN in Indonesia. This research was conducted in five provinces, which received the project of FHN from 1997 to 2002. They were North Sumatra,, Jambi, Bengkulu, Central Kalimantan, and South Kalimantan. The data of the research were taken from the respondents from August to September 2003. The population of the research was all families nurtured by the project of FHN in three selected districts each of the provinces.

To determine the villages selected for the subject taking of the research, this research employed a stratified random sampling method; three districts were selected from each province. One sub-district was plotted from each district, and then three villages from each selected sub-district were chosen as clusters. The number of the subjects of the research was 100 , which was selected randomly from three selected villages; the number of the subjects from two villages was 35 family heads each, and the number of the subject from the other village was 30 family heads. Thus, the number of the subjects of the research of each province was 300 family heads, and the total number of the whole samples of the five provinces was 1,500 family heads.

The data were obtained by completing the questionnaires, which was done through direct interviewing with the subjects of the research at their houses. The data gathered were demographic characteristics of family heads, which included the age of the family heads (the husbands), the age of the mothers (the wives), the educational background of the family heads, the educational background of the mothers, the occupation of the family heads and the mothers, the number of family members, and the diseases they suffered from in the last one-month. In the interview, in addition, the indicators of the HFPI were also questioned, which included house type, house floor type; potable water resources, family latrine, smoking habits, environmental indicators which included ventilation, garbage, and waste. The gathered data also contained information on nutrition, access to information, and interventions on the program of FHN, which included participation in the Joint Business Cooperative, Focus Group Discussion, Communication of Information and Education, Counseling, stimulant of environmental health, and home visit by the health attendants.

The criteria of the indicators of the HFPI were as follows: (1) the types of houses were divided into (a) temporary, (b) semi-permanent, and (c) permanent; (2) the types of house floor were classified as (a) the dirt house floor, and (b) the non-dirt house floor; (3) the potable water resources were classified as (a) using water system or well water resources and (b) using other than water system-well water resources; and (4) smoking habits were split into (a) the smoking subject and (b) the non-smoking subject.

The criteria of the other environmental health indicators were as follows: (1) the house ventilations were classified as (a) less ventilation, and (b) enough ventilation; (2) the garbage disposals were (a) thrown into specific place, (b) thrown into no specific place, and (c) others; and (3) the household wastes were (a) thrown into no specific place, (b) thrown into the sewers, and (c) others.

The intervention of the FHN included whether or not the subjects received the FHN treatments which comprised Joint Business Cooperative, Focus Group Discussion, Communication of Information and Education, stimulant of environmental health, counseling and home visit by the health attendants. ${ }^{7}$

This research only analyzed the disease of ARI in the last one-month the families nurtured by the project of FHN suffered from. Therefore, whatever the number of members of a family was attacked by the diseases of ARI was considered a single case.

The data of the research were analyzed by means of the computing program of Stata 6.0. ${ }^{9}$ To find out the probable factors to the risk factors or confounders the 
factors with the value of $p<0.25$ are potential to be the risk factors or confounders in the model. The risk factors and confounders were estimated by means of confidence interval of $95 \%$, which is based on the standard error and the value of estimated coefficient.

\section{RESULTS}

The participating subjects consisted of 1,500 houses. Table 1 shows that the prevalence rate of ARI in families was $16.7 \%$. Compared with those had low education (none/elementary), those who had junior or senior high school were more likely had a higher risk of having ARI at their homes. There was not noted that ARI was related to husband as well as the wife occupation.

As shown on Table 2, those who had enough ventilation houses than less ventilation were more likely had a higher risk to have ARI in their houses. Furthermore, there was not noted that ARI was related to housing types, source of potable water, household waste disposal, participating in group income generation or focus group discussion, other communication and education, and counseling programs.

Table 3, which is the final relationship model, it shows that compared with dirt floor houses, the nondirt house floor built before the implementation of the project of FHN decreased the risks of ARI of 51\%, however, the non-dirt house floor during the implementation of the project of FHN decreased moderately ARI of $33 \%(\mathrm{p}=0.279)$. The households which received, or have been occasionally or regularly stimulant of environmental health, $52 \%$ decreasing risks of ARI than the houses which never had such program. In term of provinces, compared to the province of North Sumatra, the other 4 provinces posses had less risks of ARI.

Table 1. Some demographic characteristics of subjects and the risks of acute respiratory infection (ARI)

\begin{tabular}{|c|c|c|c|c|c|c|c|c|}
\hline \multirow[t]{2}{*}{ Variable } & \multicolumn{2}{|c|}{$\begin{array}{c}\text { No ARI } \\
(\mathrm{N}=1259)\end{array}$} & \multicolumn{3}{|c|}{$\begin{array}{c}\text { ARI } \\
(\mathrm{N}=241)\end{array}$} & \multirow{2}{*}{$\begin{array}{c}\text { Crude } \\
\text { odds ratio }\end{array}$} & \multirow[t]{2}{*}{$95 \% \mathrm{CI}$} & \multirow[t]{2}{*}{$\mathrm{p}$} \\
\hline & $\mathrm{n}$ & $\%$ & $\mathrm{n}$ & & & & & \\
\hline \multicolumn{9}{|l|}{ Education of husband } \\
\hline None/elementary & 862 & 68.47 & & 147 & 61.0 & 1.00 & Reference & \\
\hline Junior/senior high school & 364 & 28.91 & & 89 & 36.9 & 1.43 & $1.07-1.92$ & 0.015 \\
\hline College/University & 11 & 0.87 & & 4 & 1.6 & 2.13 & $0.67-6.79$ & 0.200 \\
\hline Others & 22 & 1.75 & & 1 & 1.0 & 0.27 & $0.04-1.00$ & 0.198 \\
\hline \multicolumn{9}{|l|}{ Education of wife } \\
\hline None/elementary & 914 & 73.65 & & 148 & 61.7 & 1.00 & Reference & \\
\hline Junior/senior high school & 300 & 24.17 & & 90 & 37.5 & 1.85 & $1.38-2.48$ & 0.000 \\
\hline College/University & 2 & 0.00 & & 0 & 0.0 & $\mathrm{n} / \mathrm{a}$ & $\mathrm{n} / \mathrm{a}$ & $\mathrm{n} / \mathrm{a}$ \\
\hline Others & 25 & 2.02 & & 2 & 0.8 & 0.49 & $0.11-2.11$ & 0.341 \\
\hline \multicolumn{9}{|l|}{ Occupation of husband } \\
\hline None/housewife & 49 & 3.9 & & 11 & 4.6 & 1.00 & Reference & \\
\hline Labor/farmer & 1113 & 88.4 & & 215 & 89.2 & 0.86 & $0.44-1.68$ & 0.660 \\
\hline Self-employed/office & 68 & 5.4 & & 12 & 1.0 & 0.78 & $0.32-1.93$ & 0.599 \\
\hline Armed forces/Police & 12 & 1.0 & & 1 & 0.4 & 0.70 & $0.37-0.40$ & 0.365 \\
\hline Others & 17 & 1.4 & & 2 & 0.8 & 0.52 & $0.10-2.61$ & 0.430 \\
\hline \multicolumn{9}{|l|}{ Occupation of wife } \\
\hline None/housewife & 527 & 42.5 & & 94 & 39.0 & 1.00 & Reference & \\
\hline Labor/farmer & 661 & 53.3 & & 137 & 57.0 & 1.16 & $0.87-1.55$ & 0.304 \\
\hline Self-employed/office & 51 & 4.1 & & 9 & 3.7 & 0.99 & $0.18-1.95$ & 0.977 \\
\hline Armed forces/Police & 1 & 0.1 & & 0 & 0.0 & $\mathrm{n} / \mathrm{a}$ & $\mathrm{n} / \mathrm{a}$ & $\mathrm{n} / \mathrm{a}$ \\
\hline Others & 1 & 0.1 & & 0 & 0.0 & $\mathrm{n} / \mathrm{a}$ & $\mathrm{n} / \mathrm{a}$ & $\mathrm{n} / \mathrm{a}$ \\
\hline
\end{tabular}

$\mathrm{n} / \mathrm{a}=$ not applicable 
Table 2. Environmental, FHN interventions and the risks of acute respiratory infection (ARI)

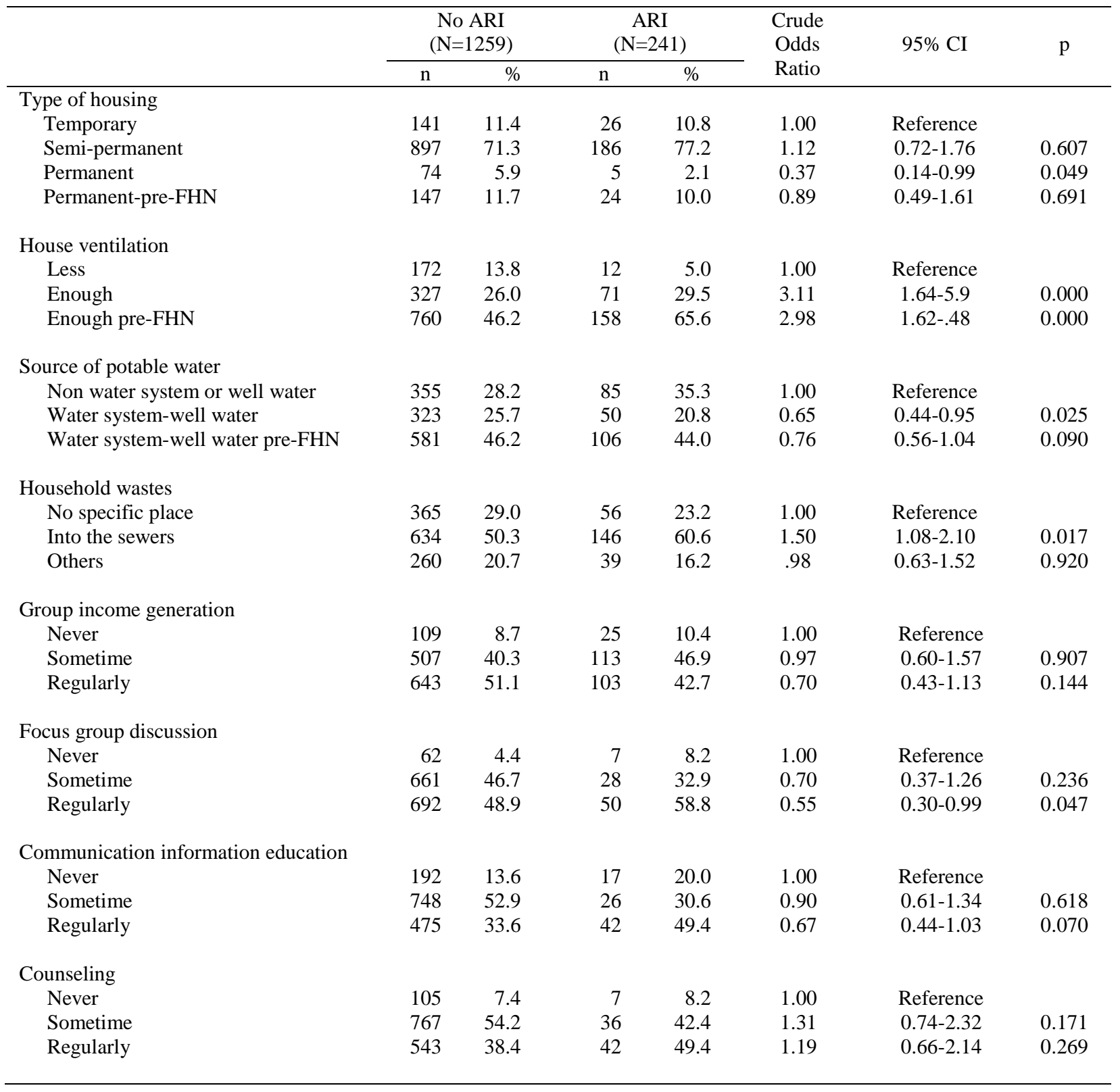


Table 3. Relationship between house floor, stimulants of environmental health, province and risks of acute respiratory infection $(\mathrm{ARI})$

\begin{tabular}{|c|c|c|c|c|c|c|c|}
\hline \multirow[t]{2}{*}{ Variables } & \multicolumn{2}{|c|}{$\begin{array}{c}\text { No ARI } \\
(\mathrm{N}=1259)\end{array}$} & \multicolumn{2}{|c|}{$\begin{array}{c}\text { ARI } \\
(\mathrm{N}=241)\end{array}$} & \multirow{2}{*}{$\begin{array}{c}\text { Adjusted } \\
\text { Odds Ratio }\end{array}$} & \multirow{2}{*}{$\begin{array}{c}95 \% \text { CI } \\
\text { Odds Ratio }\end{array}$} & \multirow[t]{2}{*}{$\mathrm{p}$} \\
\hline & $\mathrm{n}$ & $\%$ & $\mathrm{n}$ & $\%$ & & & \\
\hline \multicolumn{8}{|l|}{ House floor } \\
\hline Dirt & 51 & 4.1 & 14 & 5.8 & 1.00 & Reference & \\
\hline Non-dirt & 260 & 20.7 & 46 & 19.1 & 0.67 & $0.32-1.38$ & 0.279 \\
\hline Non-dirt - Pre FHN & 948 & 75.3 & 181 & 75.1 & 0.49 & $0.25-0.96$ & 0.038 \\
\hline \multicolumn{8}{|c|}{ Stimulant of environmental health } \\
\hline Never & 504 & 40.0 & 140 & 58.1 & 1.00 & Reference & \\
\hline Sometime & 447 & 35.5 & 62 & 25.7 & 0.48 & $0.33-0.70$ & 0.000 \\
\hline Regularly & 308 & 24.4 & 39 & 16.2 & 0.48 & $0.32-0.73$ & 0.001 \\
\hline \multicolumn{8}{|l|}{ Province } \\
\hline North Sumatra & 210 & 16.7 & 90 & 37.3 & 1.00 & Reference & \\
\hline Jambi & 267 & 21.2 & 33 & 13.7 & 0.28 & $0.17-0.46$ & 0.000 \\
\hline Bengkulu & 261 & 20.7 & 39 & 16.2 & 0.48 & $0.29-0.79$ & 0.004 \\
\hline Central Kalimantan & 237 & 18.8 & 63 & 26.1 & 0.61 & $0.39-0.96$ & 0.032 \\
\hline South Kaltim & 284 & 22.6 & 16 & 6.6 & 0.13 & $0.07-0.23$ & 0.000 \\
\hline
\end{tabular}

* Adjusted each other for variables listed on this table, house ventilation and group income generation

\section{DISCUSSION}

This research has several limitations, which may interfere the interpretations on the data of the research. Firstly, the number of the ARI cases is not calculated according to each single case basis, but the case per family, meaning that if there are more than one family members suffering from the ARI they are calculated as a single case. Secondly, the morbidity of the disease was limited to complaints felt during the last one month.

The ARI is an environment-based disease. The factor of environment contributing to the risks of ARI cases, among others, was noted the house floor. In the five provinces of the research, are most of semipermanent houses $(71.3 \%)$ with a larger number of wooden house floors, and a smaller number of dirt or concrete house floors. However, the house floors had an improvement from the dirt house floors to the nondirt house floors, and the number of the non-dirt house floors doubles five times bigger than the number of the dirt house floors during the FHN project. Such improvement was expected to much more reduce the risks of ARI cases, as contributed by the non-dirt house floors, which were built prior to the implementation of the project of FHN, and successfully reduced the risks of ARI cases. This result is supported by the results of the research conducted in Rio de Janeiro, that houses' bad conditions are the risk factors for ARI cases. The other studies conducted in India, China, and Metro Manila show that the houses' conditions, which were not standard, will increase the number of ARI cases. ${ }^{5,10,11}$

The improvement of infrastructures particularly on the environmental health takes a very important role in the risks of ARI cases. This is proven by the fact that the risks of ARI cases decreased in the community which received or had been receiving the stimulant of environmental health compared with the risks of ARI cases in the community which never receives such stimulant of environmental health FHN project. This result was in accordance with the result of research on the relation of the environmental and social economic factors to the morbidity of ARI in all provinces in Indonesia where the risk factors for ARI consist of disturbance of fumes produced by factory, the house location in the area prone to flooding (1.2 times), and the poor economic status $(0.89$ time $){ }^{2}$ Based on the research conducted by WHO some of the risk factors for ARI are milk bottle, population density, in-door and out-door pollution, and malnutrition. ${ }^{5}$ The other studies conducted Brazil dan di China also show that 
the conditions of the house surrounding have a significant influence on the number of ARI cases, meaning that the improvement of infrastructures in the filed of environmental health is expected to reduce the number of ARI cases. ${ }^{12,13}$

Among the five provinces receiving the FHN project, the provinces of Jambi, Bengkulu, Central Kalimantan dan South Kalimantan had a lower risks of ARI compared to the province of North Sumatra. We found that smoking were more likely higher prevalence in North Sumatra This result is similar with the other research that smoking is the important determinant for ARI. ${ }^{14}$

In conclusion, special attention is necessary to be addressed to the subjects with the dirt house floors. The province of North Sumatra needs to be given this special attention as it has higher risks of ARI cases than the other 4 provinces.

\section{Acknowledgment}

We thank all participating subjects, Health Office and Community Health Center staff in the five provinces of the FHN project. Our deepest gratitude's are also expressed to the Health Department through the project of ADB loan. Last but not least, our gratitude's are also presented to Prof. Bastaman Basuki for his advice and guidance on the preliminary drafts of this manuscript.

\section{REFERENCES}

1. World Health Organization. The world report 1995; bridging the gap. Geneva: The organization; 1995.

2. Cruz JR, Pareja G, de Fernandez A, Peralta F, Caceres P, Cano F. Epidemiology of acute respiratory tract infections among Guatemalan ambulatory preschool children. Rev Infect Dis. 1990; 12:S1029-34.

3. Vathanophas K, Sangchai R, Raktham S, Pariyanonda A, Thangsuvan J, Bunyaratabhandu P, et al. A communitybased study of acute respiratory tract infection in Thai children, J Epidemiol Comm Health 2003; 57: 770.

4. Etiler N, Velipsaoglu S, Aktekin M. Incidence of acute respiratory infection and the relationship with some factors in infancy in Antalya, Turkey. Pediatric Int . 2002. 44 (1): 64-9.

5. Zaman K, Baqui AH, Yunus M, Sack RB, Bateman OM, Chowdhury HR, Black RE. Acute respiratory infections in children : a community - based longitudinal study in rural Bangladesh. J Top Pediatr. 1997; 43(3):133-7.

6. Biswas A, Biswas R, Manna B, Dutta K. Risk factors of acute infections in under fives of urban slum community. Indian J Public Health. 1999.43; 73-5

7. Trihono. Progress report on family health and nutrition project [Indonesian]. Jakarta: Ministry of Health Rep of Indones; 2001.

8. Murti B. Principles of research methodology [Indonesian]. Vol 2. 2nd ed. Yogyakarta: Gadjahmada University Press; 2003.

9. Stata Corp. Stata statistical software: Release 6.0. University Drive East College Station, Texas: 1999.

10. Acharya D, Prasanna KS, Nair S, Rao RS. Acute respiratory infections in children : a community based longitudinal study in south India. Indian J Public Health 2003; 47(1):7-13.

11. Tupasi TE, de Leon LE, Lupisan S, Torres CU, Leonor ZA, Sunico ES, et all. Patterns of acute respiratory tract infection in children; a longitudinal studi in a depressed community in Metro Manila. Rev Infect Dis. 1990. 12:S940-9.

12. Barata RC, Waldman EA, de Moraes JC, Guibu IA, Rosov T, Takimoto S. Gastroenteritis and acute respiratory infections among children under 5 years old in area of southeastern Brazil, 1986 - 1987. Rev Saude Publica, 1996; 30(6):553-63.

13. Tumwesigire, Barton T. Environmental risk factors for acute respiratory among children of military personnel in Uganda. J Trop Pediatr. 1995. 41(1):8-13.

14. Ines Ackerl Kristensen. Community study of acute respiratory infections in children less than one year of age. Dan Med Bull. 2004; 3: S308. 